\title{
The ten reasons why corticosteroid therapy reduces mortality in severe COVID-19
}

\author{
Yaseen M. Arabi ${ }^{*}$ (D), George P. Chrousos ${ }^{2}$ and G. Umberto Meduri ${ }^{3,4}$
}

๑ 2020 Springer-Verlag GmbH Germany, part of Springer Nature

The recent finding of the effectiveness of corticosteroid therapy in reducing mortality in patients with severe coronavirus disease-19 (COVID-19) is a welcome breakthrough [1-6]. In this article, we highlight the current understanding of the effect of corticosteroid therapy in severe COVID-19.

1. Evidence of effectiveness from randomized controlled trials in hospitalized patients with COVID-19.

The RECOVERY randomized controlled trial (RCT) demonstrated that dexamethasone ( $6 \mathrm{mg}$ daily for 10 days) in hospitalized patients with COVID-19 reduced (i) 28-day mortality (rate ratio 0.83; 95\% confidence interval [CI], 0.75-0.93), (ii) duration of hospitalization and (iii) progression to invasive mechanical ventilation [1]. The greatest mortality reduction was observed in those receiving oxygen supplementation or invasive mechanical ventilation; no improvement was observed in those without respiratory support [1]. A prospective meta-analysis of 7 RCTs further confirmed the benefit of corticosteroid therapy in reducing mortality critically ill patients with COVID-19 (summary odds ratio [OR] 0.66, 95\% CI, 0.53-0.82) [2]. This is the best direct evidence supporting corticosteroid therapy in severe COVID-19.

2. Evidence of effectiveness in non-viral acute respiratory distress syndrome (ARDS).

A recent Spanish RCT $(n=277)$ of patients with moderate-to-severe ARDS, found that dexametha-

\footnotetext{
*Correspondence: yaseenarabi@yahoo.com

${ }^{1}$ Intensive Care Department, King Abdullah International Medical

Research Center, Ministry of National Guard Health Affairs, King Saud Bin Abdulaziz University for Health Sciences, Riyadh, Kingdom of Saudi Arabia

Full author information is available at the end of the article
}

sone (20 $\mathrm{mg}$ and $10 \mathrm{mg}$ for 5 days each), in comparison to placebo, was associated with more mechanical ventilation-free days and lower mortality. An updated meta-analysis of ten RCTs shows that corticosteroid therapy initiated before day 14 of ARDS was associated with a significant reduction in duration of mechanical ventilation and hospital mortality (risk ratio [RR] 0.67; 95\% CI 0.52-0.87) [7].

3. Evidence of effectiveness in community-acquired pneumonia.

Several systematic reviews demonstrated that in patients hospitalized with community-acquired pneumonia (CAP), corticosteroid therapy was associated with reduction in mortality, length of stay and time to clinical stability [8].

4. Dysregulated immune response in COVID-19.

Corticosteroid therapy aims to support the central regulatory function of the activated glucocorticoid receptor $\alpha(\mathrm{GC}-\mathrm{GR} \alpha)$ throughout disease development and resolution. The dysregulated immune response observed in COVID-19 is qualitatively similar to that of multifactorial ARDS [9]. In patients with severe COVID-19, glucocorticoid receptor expression in bronchoalveolar lavage myeloid cells is negatively related to lung neutrophilic inflammation, NETosis, and severity of symptoms [10]. Translational research in ARDS patients randomized to methylprednisolone has demonstrated the ability of corticosteroid therapy to rescue the cellular concentrations and functions of activated GC-GR $\alpha$ leading to downregulation of systemic and pulmonary nuclear factor- $\mathrm{kB}$-activated markers of inflammation, coagulation, and fibroproliferation [11, 12]. Biological improvement was associated with accelerated disease resolution [11]. Further work is needed

\section{望 Springer}


to understand the effect of corticosteroid therapy on the immune response to COVID-19.

5. Computed tomographic and pathology findings.

Computed tomographic findings of ground glass appearance and histopathologic features (post-mortem studies) of diffuse alveolar damage and acute fibrinous and organizing pneumonia [13] are consistent with corticosteroid-responsive inflammatory lung diseases.

6. The role of hypothalamic-pituitary-adrenal axis.
Evidence from studies of severe acute respiratory syndrome (SARS) suggest that infection with SARSCoV-2 is associated with impaired cortisol stress response (Fig. 1).

7. Microthrombi and coagulopathy.

The pathogenesis of COVID-19 illness appears to be induced by dysregulated systemic and pulmonary inflammation, along with endothelial injury, hypercoagulability and thrombosis $[14,15]$. Platelet-fibrin thrombi formation in small arterial vessels are com-

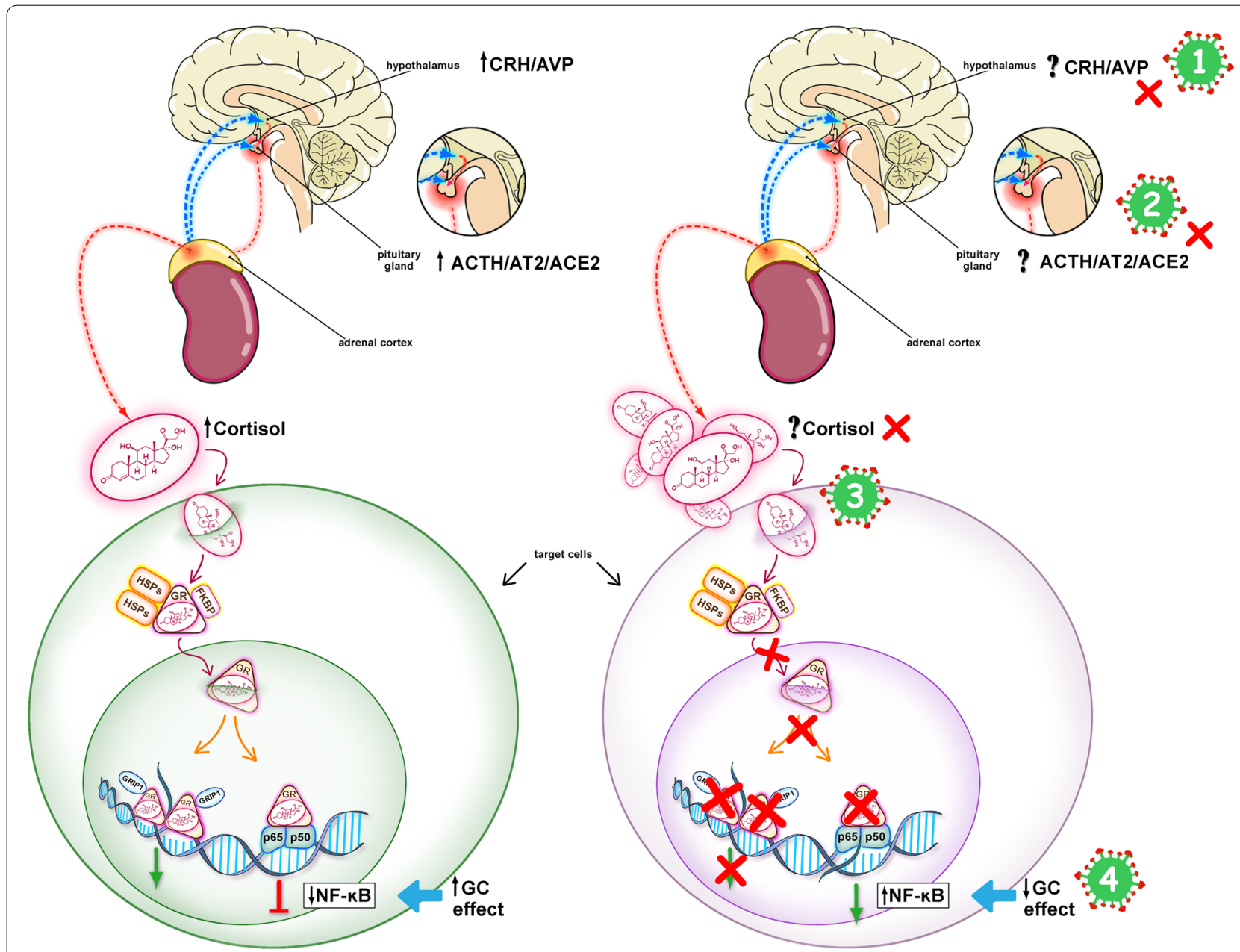

Fig. 1 Hypothalamic-pituitary-adrenal (HPA) response in COVID-19. The left panel shows an intact HPA axis response to stress leading to the downregulation of NF-kB. The right panel shows mechanisms potentially involved in an impaired HPA axis response to stress in COVID-19. COVID-19 may be associated with $\mathrm{CIRCl}$, as a result of inhibition of the hypothalamic-pituitary-adrenal (HPA) axis at any or all of its levels, as shown by the red X's: (1) Hypothalamus (CRH/AVP), (2) pituitary gland (ACTH/AT2/ACE2), (3) adrenal cortex (cortisol), and (4), target tissues (Glucocorticoid receptor signaling system). In CIRCI, target tissue resistance to glucocorticoids may occur even in the presence of elevated levels of circulating cortisol. SARS -COV-2 has an epitope that binds the ACE2 enzyme facilitating entry into host cells, which might influence the function of the HPA axis at level (2). SARS-CoV-2 may have an ACTH-mimic peptide that could act as an agonist or antagonist at the ACTH receptor at level (3). Prolonged glucocorticoid treatment is indicated when cortisol production and/or target tissue sensitivity to cortisol are compromised (Online Supplement for Supplementary References). CIRCI Critical illness-related corticosteroid insufficiency, CRH corticotropin-releasing hormone, AVP arginine-vasopressin, ACE2 angiotensin-converting enzyme 2, AT2 angiotensin 2, ACTH corticotropin, GR glucocorticoid receptor-al pha, HSP heat shock protein, FKBP immunophilin, GRIP1 coactivator, p65/p50 nuclear factor (NF)-kB 
monly observed in post-mortem examination of the lungs from patients with COVID-19 [16]. Emerging data indicate that hypercoagulability in COVID19 is induced by dysregulated release of neutrophil extracellular traps (NETs). In an equine experimental model, dexamethasone decreased NETs formation [17], which may contribute to the observed benefit from corticosteroid therapy in COVID-19.

8. Acceptable safety profile.

Short-term (up to 4 weeks) corticosteroid therapy in patients with life-threatening systemic inflammation is well-tolerated. Data from systematic reviews in CAP and ARDS showed that corticosteroid therapy was associated with transient hyperglycemia but did not increase the frequency of gastrointestinal hemorrhage, neuromuscular weakness, or nosocomial infections $[8,12]$. Hyperglycemia did not affect outcome. Recent data have provided evidence that the $\mathrm{GR} \alpha$ is essential for activation and reinforcement of innate immunity and when applied correctly (i.e., appropriate duration of corticosteroid administration) is associated with restoration of anatomy and function of the affected tissues, along with a parallel support of adaptive immunity. Corticosteroid treatment-associated downregulation of systemic and pulmonary inflammation might lower the risk of developing nosocomial infections by (i) decreasing duration of mechanical ventilation, (ii) achieving an inflammatory milieu less favorable to intraand extra- cellular growth of bacterial pathogens frequently encountered in ARDS (Staphylococcus aureus, Pseudomonas aeruginosa, and Acinetobacter sps.), and (iii) improving opsonization-dependent phagocytic neutrophil function and intracellular killing [18]. (Online Supplement for Supplementary References).

9. Long-term outcome.

In RCTs of ARDS patients, corticosteroid therapy was associated with survival benefit that persisted after up to one year of hospital discharge (limit of measurement) [19]. Extensive literature suggests pro-inflammatory cytokines do influence the brain, and may be involved in the pathogenesis of depression and post-traumatic stress disorder (PTSD). Data from five small RCTs $(n=292)$ suggest that longer duration of corticosteroid therapy may be associated with lower anxiety scores and improved PTSD symptomatology. Corticosteroid therapy-associated reduction in duration of mechanical ventilation and sedation may also have a positive impact on long-term PTSD symptoms and cognitive function. (Online Supplement for Supplementary References).
10. Scalability.

The low cost and wide availability make corticosteroid therapy easily equitable and available globally across different income settings.

Recent data on corticosteroid therapy represent a milestone in the of management of COVID-19, while many questions remain. Efforts for worldwide implementation of corticosteroid therapy protocols should be supported by data regarding generalizability of the observed effect in randomized controlled trials across subgroups of patients, different populations, and resource settings. More data are needed to evaluate the impact of type of corticosteroid, timing of initiation, dose, mode of administration, duration, and dose tapering on outcome. And also to (i) identify modalities to adjust treatment dose and duration based on laboratory parameters of oxygenation and inflammation, and (ii) to evaluate the impact of co-interventions directed at improving response to corticosteroid therapy [20]. Limited data are presently available on the impact of corticosteroid therapy on SARS $\mathrm{CoV}-2$ replication, and on the potential benefits of concomitant antiviral treatment. The interaction between corticosteroid therapy and other COVID-19 therapeutics, such as interferons (IFNs) [21] and anticoagulation should be explored.

In conclusion, corticosteroid therapy is a safe and effective intervention in downregulating the integrated pathways of inflammation-coagulation-fibroproliferation, in the lung and systemically, in COVID-19 patients. There is an ethical urgency to invest in this field of research.

\section{Electronic supplementary material}

The online version of this article (https://doi.org/10.1007/s00134-020-06223-y) contains supplementary material, which is available to authorized users.

\section{Author details \\ ${ }^{1}$ Intensive Care Department, King Abdullah International Medical Research Center, Ministry of National Guard Health Affairs, King Saud Bin Abdulaziz University for Health Sciences, Riyadh, Kingdom of Saudi Arabia. ${ }^{2}$ University Research Institute of Maternal and Child Health and Precision Medicine, Medi- cal School, National and Kapodistrian University of Athens, Athens, Greece. ${ }^{3}$ Memphis Veterans Affairs Medical Center Research Service and Pulmonary, Critical Care, and Sleep Medicine Service, Memphis, TN, USA. ${ }^{4}$ Department of Medicine, University of Tennessee Health Science Center, Memphis, TN, USA.}

\section{Funding}

GUM reports support with the resources and use of facilities at the Memphis VA Medical Center. The contents of this commentary do not represent the views of the U.S. Department of Veterans Affairs or the United States Government.

\section{Compliance with ethical standards}

Conflicts of interest

The authors declare no conflict of interest.

\section{Publisher's Note}

Springer Nature remains neutral with regard to jurisdictional claims in published maps and institutional affiliations. 
Received: 29 July 2020 Accepted: 19 August 2020

Published online: 7 October 2020

\section{References}

1. RECOVERY Collaborative Group, Horby P, Lim WS, Emberson JR, Mafham M, Bell JL, Linsell L, Staplin N, Brightling C, Ustianowski A, Elmahi E, Prudon B, Green C, Felton T, Chadwick D, Rege K, Fegan C, Chappell LC, Faust SN, Jaki T, Jeffery K, Montgomery A, Rowan K, Juszczak E, Baillie JK, Haynes R, Landray MJ (2020) Dexamethasone in hospitalized patients with Covid19_Preliminary Report. N Engl J Med. https://doi.org/10.1056/NEJMo a2021436

2. WHO REACT Working Group, Sterne JAC, Murthy S, Diaz JV, Slutsky AS Villar J, Angus DC, Annane D, Azevedo LCP, Berwanger O, Cavalcanti $A B$, Dequin PF, Du B, Emberson J, Fisher D, Giraudeau B, Gordon AC, Granholm A, Green C, Haynes R, Heming N, Higgins JPT, Horby P, Juni P, Landray MJ, Le Gouge A, Leclerc M, Lim WS, Machado FR, McArthur C, Meziani F, Moller MH, Perner A, Petersen MW, Savovic J, Tomazini B, Veiga VC, Webb S, Marshall JC (2020) Association Between Administration of Systemic Corticosteroids and Mortality Among Critically III Patients With COVID-19: A Meta-analysis. JAMA. https://doi.org/10.1001/ jama.2020.17023

3. Lamontagne F, Agoritsas T, Macdonald H, Leo YS, Diaz J, Agarwal A, Appiah JA, Arabi Y, Blumberg L, Calfee CS, Cao B, Cecconi M, Cooke G, Dunning J, Geduld H, Gee P, Manai H, Hui DS, Kanda S, Kawano-Dourado L, Kim YJ, Kissoon N, Kwizera A, Laake JH, Machado FR, Qadir N, Sarin R, Shen Y, Zeng L, Brignardello-Petersen R, Lytvyn L, Siemieniuk R, Zeraatkar D, Bartoszko J, Ge L, Maguire B, Rochwerg B, Guyatt G, Vandvik PO (2020) A living WHO guideline on drugs for covid-19. BMJ 370:m3379. https:// doi.org/10.1136/bmi.m3379

4. Writing Committee for the REMAP-CAP, Angus DC, Derde L, Al-Beidh F, Annane D, Arabi Y, Beane A, van Bentum-Puijk W, Berry L, Bhimani Z, Bonten M, Bradbury C, Brunkhorst F, Buxton M, Buzgau A, Cheng AC, de Jong M, Detry M, Estcourt L, Fitzgerald M, Goossens H, Green C, Haniffa R, Higgins AM, Horvat C, Hullegie SJ, Kruger P, Lamontagne F, Lawler PR, Linstrum K, Litton E, Lorenzi E, Marshall J, McAuley D, McGlothin A, McGuinness S, McVerry B, Montgomery S, Mouncey P, Murthy S, Nichol A, Parke R, Parker J, Rowan K, Sanil A, Santos M, Saunders C, Seymour C, Turner A, van de Veerdonk F, Venkatesh B, Zarychanski R, Berry S, Lewis RJ, McArthur C, Webb SA, Gordon AC (2020) Effect of hydrocortisone on mortality and organ support in patients with severe COVID-19: the REMAP-CAP COVID-19 corticosteroid domain randomized clinical trial. JAMA. https://doi.org/10.1001/jama.2020.17022.

5. Tomazini BM, Maia IS, Cavalcanti AB, Berwanger O, Rosa RG, Veiga VC, Avezum A, Lopes RD, Bueno FR, Silva M, Baldassare FP, Costa ELV, Moura RAB, Honorato MO, Costa AN, Damiani LP, Lisboa T, Kawano-Dourado L, Zampieri FG, Olivato GB, Righy C, Amendola CP, Roepke RML, Freitas DHM, Forte DN, Freitas FGR, Fernandes CCF, Melro LMG, Junior GFS, Morais DC, Zung S, Machado FR, Azevedo LCP, Investigators CC-BI (2020) Effect of dexamethasone on days alive and ventilator-free in patients with moderate or severe acute respiratory distress syndrome and COVID19: the CoDEX randomized clinical trial. JAMA. https://doi.org/10.1001/ jama.2020.17021

6. Dequin PF, Heming N, Meziani F, Plantefeve G, Voiriot G, Badie J, Francois B, Aubron C, Ricard JD, Ehrmann S, Jouan Y, Guillon A, Leclerc M, Coffre C, Bourgoin H, Lengelle C, Caille-Fenerol C, Tavernier E, Zohar S, Giraudeau B, Annane D, Le Gouge A, Group CCT, the C-TN (2020) Effect of hydrocortisone on 21-day mortality or respiratory support among critically III patients with COVID-19: a randomized clinical trial. JAMA. https://doi. org/10.1001/jama.2020.16761
7. Villar J, Confalonieri M, Pastores SM, Meduri GU (2020) Rationale for prolonged corticosteroid treatment in the acute respiratory distress syndrome caused by Coronavirus disease 2019. Crit Care Explor 2:e0111

8. Torres A, Ferrer M, Niederman MS (2018) Adjuvant therapies in critical care: steroids in community-acquired pneumonia. Intensive Care Med 44:478-481

9. Azkur AK, Akdis M, Azkur D, Sokolowska M, van de Veen W, Bruggen MC, O'Mahony L, Gao Y, Nadeau K, Akdis CA (2020) Immune response to SARS-CoV-2 and mechanisms of immunopathological changes in COVID19. Allergy 75:1564-1581

10. Park JH, Lee HK (2020) Re-analysis of single cell transcriptome reveals that the NR3C1-CXCL8-neutrophil axis determines the severity of COVID-19. Front Immunol 11:2145

11. Meduri GU, Annane D, Chrousos GP, Marik PE, Sinclair SE (2009) Activation and regulation of systemic inflammation in ARDS: rationale for prolonged glucocorticoid therapy. Chest 136:1631-1643

12. Annane D, Pastores SM, Arlt W, Balk RA, Beishuizen A, Briegel J, Carcillo J, Christ-Crain M, Cooper MS, Marik PE, Meduri GU, Olsen KM, Rochwerg B, Rodgers SC, Russell JA, Van den Berghe G (2017) Critical illness-related corticosteroid insufficiency (CIRCI): a narrative review from a multispecialty task force of the society of critical care medicine (SCCM) and the European society of intensive care medicine (ESICM). Intensive Care Med 43:1781-1792

13. Copin MC, Parmentier E, Duburcq T, Poissy J, Mathieu D, Lille C-I, Anatomopathology G (2020) Time to consider histologic pattern of lung injury to treat critically ill patients with COVID-19 infection. Intensive Care Med 46:1124-1126

14. Joly BS, Siguret V, Veyradier A (2020) Understanding pathophysiology of hemostasis disorders in critically ill patients with COVID-19. Intensive Care Med 46:1603-1606

15. Helms J, Tacquard C, Severac F, Leonard-Lorant I, Ohana M, Delabranche X, Merdji H, Clere-JehI R, Schenck M, Fagot Gandet F, Fafi-Kremer S, Castelain V, Schneider F, Grunebaum L, Angles-Cano E, Sattler L, Mertes PM, Meziani F, Group CT (2020) High risk of thrombosis in patients with severe SARS-CoV-2 infection: a multicenter prospective cohort study. Intensive Care Med 46:1089-1098

16. Carsana L, Sonzogni A, Nasr A, Rossi RS, Pellegrinelli A, Zerbi P, Rech R, Colombo R, Antinori S, Corbellino M, Galli M, Catena E, Tosoni A, Gianatti A, Nebuloni M (2020) Pulmonary post-mortem findings in a series of COVID-19 cases from northern Italy: a two-centre descriptive study. Lancet Infect Dis. https://doi.org/10.1016/S1473-3099(20)30434-5

17. Vargas A, Boivin R, Cano P, Murcia Y, Bazin I, Lavoie JP (2017) Neutrophil extracellular traps are downregulated by glucocorticosteroids in lungs in an equine model of asthma. Respir Res 18:207

18. Kaufmann I, Briegel J, Schliephake F, Hoelzl A, Chouker A, Hummel T, Schelling G, Thiel M (2008) Stress doses of hydrocortisone in septic shock: beneficial effects on opsonization-dependent neutrophil functions. Intensive Care Med 34:344-349

19. Meduri GU, Siemieniuk RAC, Ness RA, Seyler SJ (2018) Prolonged lowdose methylprednisolone treatment is highly effective in reducing duration of mechanical ventilation and mortality in patients with ARDS. J Intensive Care 6:53

20. Meduri GU, Chrousos GP (2020) General adaptation in critical illness: glucocorticoid receptor-alpha master regulator of homeostatic corrections. Front Endocrinol 11:161

21. Jalkanen J, Pettila V, Huttunen T, Hollmen M, Jalkanen S (2020) Glucocorticoids inhibit type I IFN beta signaling and the upregulation of CD73 in human lung. Intensive Care Med 